\title{
Production of Baby-leaf Salad Greens in the Spring and Fall Seasons of Northwest Washington
}

\author{
Charlene M. Grahn \\ Department of Horticulture, Washington State University, Northwestern \\ Washington Research and Extension Center, 16650 State Route 536, Mount \\ Vernon, WA 98273
}

\section{Chris Benedict}

Whatcom County Extension, Washington State University, $1000 \mathrm{~N}$ Forest Street, Suite 201, Bellingham, WA 98225

\section{Tom Thornton \\ Cloud Mountain Farm Center, 6906 Goodwin Road, Everson, WA 98247}

Carol Miles ${ }^{1}$

Department of Horticulture, Washington State University, Northwestern Washington Research and Extension Center, 16650 State Route 536, Mount Vernon, WA 98273

Additional index words. lettuce, spinach, arugula, kale, pak choi, bok choi, beet, mustard

\begin{abstract}
Baby-leaf salad green crops such as lettuce (Lactuca sativa), kale (Brassica oleracea), arugula (Eruca sativa), and mustard greens (Brassica juncea) thrive in the cool, humid climate of the maritime Pacific Northwest, particularly in the extended spring and fall seasons. To identify cultivars best suited for extended-season production in northwest Washington, nine leafy green cultivars were grown at two locations in the spring and fall seasons for 2 years. A high level of variability in crop performance was observed between seasons, locations, years, planting dates, and cultivars, indicating low-yield stability in baby-leaf salad crops across diverse environments and conditions. Overall, cultivars had a higher marketable weight in the spring than in the fall. Marketable weight was higher in Spring 2013 than in Spring 2014, and was higher in Fall 2013 than in Fall 2012. Days to harvest (DTH) were shorter in the spring than in the fall both years, and in both seasons DTH varied by $\approx 1$ week between the two trial locations. Fresh weed biomass was almost 5.5 times higher in spring than in fall both years. Overall, pak choi 'Joi Choi' and mustard 'Komatsuna' had the highest marketable weight, lowest DTH, and lowest weed biomass across the widest range of environments and conditions, while beet 'Bull's Blood' had the lowest marketable weight, relatively long DTH and highest weed biomass. These results suggest that baby-leaf salad crop cultivar selection differs for spring and fall seasons, and production can be highly variable between years and locations. Further, results suggest that growers should plant a diversity of crop cultivars each season to protect from crop loss and to achieve overall yield stability.
\end{abstract}

Ready-to-eat salad mix has experienced more than a 5-fold increase in supermarket sales over the last 20 years in the United States, increasing from \$197 million in 1993 to $\$ 2.7$ billion in 2008 , while the sales of iceberg and romaine head lettuce have decreased (Cook, 2008). Bagged ready-to-eat

Received for publication 24 June 2015. Accepted for publication 5 Aug. 2015.

We thank Wild Garden Seed, Philomath, OR; Johnny's Selected Seeds, Winslow, ME; and Osborne Seed Company, Mount Vernon, WA; for donating the seed used in this experiment. Funding support from the Washington State Department of Agriculture Specialty Crop Block Grant Program and the Washington State University Emerging Research Issues Extension grant are gratefully acknowledged.

${ }^{1}$ Corresponding author. E-mail: milesc@wsu.edu. originated with the concept of mesclun, or "spring mix" in Provence, France, in the 1700s and was introduced to American cuisine in metropolitan restaurants in the late 1960s (Hardesty, 2010).

Growers in California and Arizona are able to produce leafy green salad crops yearround because of the region's mild winter climate (Koike et al., 2011; Reader, 2003; Smith et al., 2011). These two states accounted for $96 \%$ of all lettuce grown in the United States in 2012, and the Salinas Valley alone accounted for $70 \%$ of leafy green salad crops (City of Salinas Economic Development, 2013; USDA, 2010), which included 57,200 t of spring mix, $15,100 \mathrm{t}$ of baby-leaf spinach, $11,800 \mathrm{t}$ of radicchio (Cichorium intybus $\mathrm{L}$.), $21,900 \mathrm{t}$ of kale, and $945,000 \mathrm{t}$ of leaf lettuce (Monterey County Crop Report, 2012). In most other states, leafy green salad crops are grown seasonally on small- and moderate-sized farms, with over $70 \%$ of lettuce and over $60 \%$ of spinach producers growing less than one-half hectare (USDA, 2010, 2012b, 2014). In Washington State, lettuce was produced on 222 farms totaling 83 ha in 2012 with leaf lettuce as the dominant lettuce type, followed by crisphead and romaine types (USDA, 2012b). Spinach was produced on 44 farms totaling 64 ha in 2012 .

There is strong demand in northwest Washington for locally grown baby-leaf salad greens. While the market is well supplied throughout the summer in this region because of the mild climate that is conducive to baby-leaf salad green production, growers require production information to enable them to extend the season as much as possible in the spring and fall. Research on salad crop production has historically focused on crop performance at the mature growth stage (Clarkson et al., 2003; Farnham and Garrett, 1996; Hoque et al., 2010; Sanchez and El-Hout, 1995; Zhao and Carey, 2009). Babyleaf salad greens are harvested between 30 and $45 \mathrm{~d}$ after planting, and in recent studies it has been shown that cultivar performance at the baby-leaf stage differs from performance at the mature stage because of physiological and morphological differences between the developmental stages (Borrelli et al., 2013; Coolong et al., 2013; Egea-Gilabert et al., 2013; Wallace et al., 2012).

The objective of this experiment was to evaluate nine salad crop cultivars for suitability as baby-leaf salad greens in the spring (April-June) and six cultivars for the fall (September-November) growing seasons in northwest Washington. Overall productivity, earliness, and ability to compete with weeds were measured.

\section{Materials and Methods} greens (Brassica juncea L. and Brassica oleracea L.), pak choi (Brassica rapa L.), kale (Brassica oleracea L.), arugula (Eruca sativa L. and Diplotaxis tenuifolia L.), and beet greens (Beta vulgaris L.) (Hardesty and Leff, 2009). Although the widespread consumption and distribution of baby-leaf salad mix is a relatively recent development in the United States, the practice of harvesting leafy greens at an immature stage of development
This study was conducted at two locations $\approx 65 \mathrm{~km}$ apart in northwest Washington: Cloud Mountain Farm Center (CMFC) in Everson, and Washington State University's Northwestern Washington Research and Extension Center (WSU NWREC) in Mount Vernon. Soil at CMFC was Squalicum gravelly loam and at WSU NWREC was Skagit 
silt loam (Table 1). Weather data including air temperature, relative humidity, soil temperature, and light transmission (photosynthetically active radiation) were monitored at both field sites with a HOBO weather station (Onset Corporation, Bourne, MA). The CMFC location was managed organically as per U.S. Department of Agriculture (USDA) guidelines, and the WSU NWREC location was in transition to certified organic. At CMFC, a mixed small grain and pea cover crop was grown before the field study, and a pea cover crop was grown previously at WSU NWREC.

At both locations the research design was a randomized complete split block with three replications. The main plot was planting date and the split plot treatment was cultivar. The study included two planting dates, 2 weeks apart, in the spring and fall seasons, and was repeated for 2 years. There were nine cultivars in the spring season, and six in the fall season; crop cultivars are provided in Table 2.

Plots were one bed wide and $10 \mathrm{~m}$ long at both locations. At CMFC, beds were $0.75 \mathrm{~m}$ wide and $8 \mathrm{~cm}$ high, and at WSU NWREC, beds were $0.75 \mathrm{~m}$ wide and $18 \mathrm{~cm}$ high; at both locations bed spacing was $\approx 1.75 \mathrm{~m}$ center-to-center. At both locations, preplant organic fertilizer Wil-Gro Proganic 8-2-4 (Wilbur-Ellis Company, Yakima, WA) was broadcast applied at $56 \mathrm{~kg} \cdot \mathrm{ha}^{-1}$ to bed centers before bed shaping. On each bed, cultivars were planted in six rows spaced $10 \mathrm{~cm}$ apart. Seed spacing within each row was $\approx 1 \mathrm{~cm}$ and planting rate was 80 seeds per meter-row to achieve a seeding density of 2.7 million seeds/ha. Irrigation was applied at a rate of $36 \mathrm{~mm} \cdot \mathrm{d}^{-1}$ three times per week and was adjusted for precipitation. At CMFC, irrigation was applied using microsprinklers (Nelson Irrigation Corporation, Walla Walla, WA), and at NWREC, drip irrigation was applied using two tapes (8-inch emitter spacing, $2.5 \mathrm{~L} / \mathrm{min} / 30.5 \mathrm{~m}$; T-Systems International, San Diego, CA) per bed spaced $20 \mathrm{~cm}$ apart equidistant from the center of the bed.

Weeds were not managed within beds so that weed growth could be measured for each cultivar. Row cover $(85 \%$ transmittance Agribon AG-19; Polymer Group Inc., Charlotte, NC) was applied to all Brassica crops (mustards 'Yukina Savoy', 'Komatsuna', and 'Bekana', kale 'Winter Red', arugula 'Adagio', and pak choi 'Joi Choi') for spring plantings at WSU NWREC in 2013 and 2014 after flea beetles were observed in those plots. Flea beetle damage at CMFC was negligible, thus rowcover was not used at this site. Rowcover was not applied during the fall at either location as no flea beetle damage was observed during that period.

Data collection. Seedling emergence was measured twice weekly in each plot until no newly emerged plants were observed within that plot for a period of 1 week. The center $1 \mathrm{~m}$ of each plot was harvested when the majority of plants had leaves $10 \mathrm{~cm}$ long (the

Table 1. Field site characteristics and climate measurements at Cloud Mountain Farm Center (CMFC) and Washington State University Northwestern Washington Research and Extension Center (NWREC) in Spring 2013 and 2014, and Fall 2012 and 2013.

\begin{tabular}{|c|c|c|c|c|}
\hline & \multicolumn{2}{|c|}{$\mathrm{CMFC}$} & \multicolumn{2}{|c|}{ NWREC } \\
\hline \multicolumn{5}{|l|}{ Site characteristics } \\
\hline Trial site elevation (m) & \multicolumn{2}{|c|}{65} & \multicolumn{2}{|c|}{6} \\
\hline Soil type t $^{z}$ & \multicolumn{2}{|c|}{ Squalicum gravelly loam } & \multicolumn{2}{|c|}{ Skagit silt loam } \\
\hline Soil $\mathrm{pH}^{\mathrm{y}}$ & \multicolumn{2}{|c|}{6.6} & \multicolumn{2}{|c|}{6.5} \\
\hline Percent organic matter ${ }^{\mathrm{y}}$ & \multicolumn{2}{|c|}{6.0} & \multicolumn{2}{|c|}{2.9} \\
\hline Range in temperature $\left({ }^{\circ} \mathrm{C}\right)^{\mathrm{x}}$ & \multicolumn{2}{|c|}{-5.5 to 33.2} & \multicolumn{2}{|c|}{-2.4 to 28.2} \\
\hline Climate measurements & Spring & Fall & Spring & Fall \\
\hline Average air temperature $\left({ }^{\circ} \mathrm{C}\right)^{\mathrm{x}}$ & 13.7 & 10.9 & 13.6 & 11.3 \\
\hline Average high air temperature $\left({ }^{\circ} \mathrm{C}\right)^{\mathrm{x}}$ & 18.8 & 16.2 & 18.6 & 15.9 \\
\hline Average low air temperature $\left({ }^{\circ} \mathrm{C}\right)^{\mathrm{x}}$ & 8.6 & 6.1 & 9.1 & 7.1 \\
\hline Total rainfall $(\mathrm{cm})^{\mathrm{w}}$ & 18.4 & 26.6 & 14.1 & 17.8 \\
\hline
\end{tabular}

${ }^{\mathrm{z} D a t a}$ from USDA NRCS Web Soil Survey (NRCS, 2012a).

${ }^{y}$ Soil test performed by Soiltest Farm Consultants Inc., Moses Lake, WA. Results combined for all years. ${ }^{\mathrm{x}}$ Measured with HOBO weather station (Onset Corporation, Bourne, MA) placed within a bed in the center of the study field, 4 feet above the soil surface. Combined data from both years.

${ }^{\text {w}}$ Total rainfall recorded during trial period by WSU AgWeatherNet Lawrence station for CMFC (5 km from the trial site) and WSU Mount Vernon station for WSU NWREC. Combined data from both years.

Table 2. Leafy green crop cultivars evaluated for baby-leaf salad production in two staggered plantings at Cloud Mountain Farm Center (CMFC) and Washington State University Northwestern Washington Research and Extension Center (NWREC) in Spring 2013 and 2014, and Fall 2012 and 2013.

\begin{tabular}{|c|c|c|c|c|c|c|}
\hline \multirow[b]{2}{*}{ Cultivar } & \multirow[b]{2}{*}{ Type } & \multirow[b]{2}{*}{ Family } & \multicolumn{2}{|c|}{ Spring } & \multicolumn{2}{|c|}{ Fall } \\
\hline & & & 2013 & 2014 & 2012 & 2013 \\
\hline Bulls Blood Beet & Beet & Amaranthaceae & $\mathrm{x}$ & $\mathrm{x}$ & $\mathrm{x}$ & $\mathrm{X}$ \\
\hline El Real & Spinach & Amaranthaceae & $\mathrm{x}$ & $\mathrm{x}$ & $-^{z}$ & 一 \\
\hline Brown Goldring & Lettuce & Asteraceae & $\mathrm{x}$ & $\mathrm{x}$ & $\mathrm{x}$ & $\mathrm{x}$ \\
\hline Adagio & Arugula & Brassicaceae & $\mathrm{x}$ & $\mathrm{x}$ & 一 & - \\
\hline Bekana & Mustard & Brassicaceae & $\mathrm{x}$ & $\mathrm{x}$ & $\mathrm{x}$ & $\mathrm{x}$ \\
\hline Joi Choi & Pak choi & Brassicaceae & $\mathrm{x}$ & $\mathrm{x}$ & $\mathrm{x}$ & $\mathrm{x}$ \\
\hline Komatsuna & Mustard & Brassicaceae & $\mathrm{x}$ & $\mathrm{x}$ & $\mathrm{x}$ & $\mathrm{x}$ \\
\hline Yukina Savoy & Mustard & Brassicaceae & $\mathrm{x}$ & $\mathrm{x}$ & $\mathrm{x}$ & $\mathrm{x}$ \\
\hline Winter Red & Kale & Brassicaceae & $\mathrm{x}$ & $\mathrm{x}$ & - & - \\
\hline
\end{tabular}

${ }^{\mathrm{z}}$ Cultivar was not included in fall plantings. marketable size for baby-leaf salad). Leaves were cut by hand $3 \mathrm{~cm}$ above the soil surface. Although it is possible to harvest baby-leaf salad crops up to three times if the crop is left in the field to regrow, data were only collected for the initial harvest of each plot. Harvest date, weight (g) of marketable leaves, and the fresh weight $(\mathrm{g})$ of weeds in the harvested area were recorded for each plot; however, weeds were not measured at CMFC in Fall 2012 due to an oversight. In this study, damage that rendered leaves unmarketable was primarily because of flea beetle feeding; an insect feeding hole larger than $0.5 \mathrm{~cm}$ in diameter classified the leaf as unmarketable per local market acceptability standards. Leaves that exhibited discoloration, decay, or disease symptoms as well as plants that had bolted were also considered unmarketable. These leaves were not included in the measured weight $(\mathrm{g})$ of marketable leaves.

Data analysis. Data were subjected to analysis of variance (ANOVA) using PROC MIXED in SAS (Statistical Analysis System Version 9.3 for Windows; SAS Institute, Cary, NC). All data were analyzed as a randomized complete split block design. Some data were transformed before analysis to meet the assumptions of normality and homogeneity of variance; the most appropriate transformation was selected using the range method described by Kirk (1982). If no transformation satisfied the assumptions of normality or homogeneity of variance, a nonparametric ANOVA was performed as described above after converting data into ranks using PROC RANK in SAS. Fischer's least significant difference test was used to compare treatment means for significant differences. Where significant interactions were detected between main effects, treatments were analyzed separately.

\section{Results}

There were significant interactions between main effects for all crop parameters measured $(P<0.05$ for all), thus data are presented separately by season, location, year, and planting date.

Marketable weight. Marketable weight was higher in spring than in fall (13.80 and $9.11 \mathrm{t} \cdot \mathrm{ha}^{-1}$, respectively; $\left.P=0.0001\right)$. Marketable weight was higher in Spring 2013 than in Spring 2014 (18.35 and $5.65 \mathrm{t} \cdot \mathrm{ha}^{-1}$, respectively; $P=0.0001)$ and was higher in Fall 2013 than in Fall 2012 (13.28 and $6.05 \mathrm{t} \cdot \mathrm{ha}^{-1}$, respectively; $P=0.0001$ ).

In the spring, marketable weight was higher at CMFC than NWREC (14.04 and 10.51 t.ha ${ }^{-1}$, respectively; $\left.P=0.006\right)$. At CMFC, marketable weight was higher for Planting 2 than Planting 1 in 2013 (16.55 and 7.57 t.ha ${ }^{-1}$, respectively; $P=0.0001$ ), whereas in 2014, marketable weight did not differ between plantings (6.60 and $7.36 \mathrm{t} \cdot \mathrm{ha}^{-1}$, respectively; $P=0.12$ ). At NWREC, marketable weight was also higher for Planting 2 than Planting 1 in 2013 (14.76 and $5.75 \mathrm{t} \cdot \mathrm{ha}^{-1}$, respectively; $P=0.0001)$, whereas in 2014 marketable weight did not differ between plantings (5.84 and $8.79 \mathrm{t} \cdot \mathrm{ha}^{-1}$, respectively; $P=0.08$ ). 
In the fall, marketable weight did not differ between CMFC and NWREC (9.91 and 9.83 t.ha ${ }^{-1}$, respectively; $P=0.18$ ). At CMFC, there was no difference between plantings in either 2012 (7.45 and $7.23 \mathrm{t} \cdot \mathrm{ha}^{-1}$, respectively; $P=0.33$ ) or 2013 (18.99 and $12.69 \mathrm{t} \cdot \mathrm{ha}^{-1}$, respectively; $P=0.95)$. At NWREC, there also was no difference in marketable weight between plantings in either 2012 (5.92 and $4.44 \mathrm{t} \cdot \mathrm{ha}^{-1}$, respectively; $P=0.64$ ) or 2013 (13.96 and 8.69 t.ha ${ }^{-1}$, respectively; $P=0.72$ ).

Overall, 'Joi Choi' and 'Bekana' had a higher marketable weight than other cultivars across the widest range of seasons, locations, years, and planting dates (seven of 11 plantings), while 'Komatsuna' had one of the highest marketable weights in six of 11 plantings (Table 3). However, 'Joi Choi' had one of the lowest marketable weights in two of 11 plantings, while 'Bekana' had one of the lowest marketable weights in one of 11 plantings (Table 3). In contrast, 'Komatsuna' never had one of the lowest marketable weights. 'Bull's Blood' had a lower marketable weight than most other cultivars across the widest range of seasons, locations, years, and planting dates (five of 11 plantings), but had one of the highest marketable weights in two plantings (Table 3 ).

Days to harvest. DTH was longer in fall than in spring (43 and $38 \mathrm{~d}$, respectively; $P=0.0001)$. In the spring, DTH was shorter at CMFC than NWREC (36 and $38 \mathrm{~d}$, respectively; $P=0.0001$ ). At CMFC, DTH was shorter in 2013 than 2014 (35 and $39 \mathrm{~d}$, respectively; $P=0.0001$ ). At this location, DTH was longer in Planting 1 than Planting 2 in both 2013 (37 and 34 d, respectively; $P=0.0001)$ and 2014 (41 and $35 \mathrm{~d}$, respectively; $P=0.0001)$. At NWREC, DTH did not differ between 2013 and 2014 (39 and 38 d, respectively; $P=0.30$ ). In 2013, DTH was longer for Planting 1 than for Planting 2 (40 and $37 \mathrm{~d}$, respectively; $P=0.001$ ), while in
2014, DTH did not differ between plantings (40 and $37 \mathrm{~d}$, respectively; $P=0.08$ ).

In the fall, DTH was shorter at CMFC than NWREC (40 and $48 \mathrm{~d}$, respectively; $P=0.0001)$. At CMFC, DTH did not differ between 2012 and 2013 ( $40 \mathrm{~d}$ both; $P=0.78$ ). At this location DTH was shorter for Planting 1 than Planting 2 in both 2013 (38 and $45 \mathrm{~d}$, respectively; $P=0.0001)$ and 2014 (37 and $44 \mathrm{~d}$, respectively; $P=0.0001$ ). At NWREC, DTH was shorter in 2013 than in 2014 ( 38 and 58 d, respectively; $P=0.0001$ ). In 2013, DTH was shorter for Planting 1 than Planting 2 (32 and $45 \mathrm{~d}$, respectively; $P=$ 0.0001 ), whereas in 2014 there was no difference in DTH between plantings (54 and $58 \mathrm{~d}$, respectively; $P=0.07$ )

Overall, 'Komatsuna', 'Joi Choi', and 'Bekana' had a lower DTH than most other cultivars across the widest range of seasons, locations, years, and planting dates $(12,11$, and 11 of 12 plantings, respectively) (Table 4). DTH for 'Komatsuna' and 'Bekana' were less than for most other cultivars; however, 'Joi Choi' had a higher DTH than most other cultivars in one planting (Table 4). 'Brown Goldring' and 'Bull's Blood' had a higher DTH than most cultivars across the widest range of seasons, locations, years, and planting dates (seven of nine plantings and six of ten plantings, respectively) (Table 4).

Weed biomass. Fresh weed biomass was higher in spring than in fall (1.47 and $0.27 \mathrm{t} \cdot \mathrm{ha}^{-1}$, respectively; $P=0.0001$ ), however, there was no difference between years $(0.93$ and 1.15 t.ha ${ }^{-1}$, respectively; $P=0.82$ ). Overall, plots of 'Komatsuna' and 'Joi Choi' had lower weed biomasses than plots of most other cultivars across the widest range of seasons, locations, years, and planting dates (eight and seven of nine total plantings, respectively) (Table 5). 'Bull's Blood' had a higher weed biomass relative to other cultivars across the widest range of seasons, locations, years, and planting dates (seven of eight plantings), and it never had a lower weed biomass relative to other cultivars (Table 5).

\section{Discussion}

In this study, there were many interactions between year, season, location, planting date, and cultivar for all crop parameters measured (marketable crop weight, days to harvest, and ability to compete with weeds). These results suggest that environmental conditions and phenotypic plasticity play an important role in the performance of baby-leaf salad crops (Bumgarner et al., 2011; Dalla Costa et al., 2011). Other studies have noted similar interactions between season and cultivar for marketable weight of arugula, as well as interactions between season and planting density in arugula (Freitas et al., 2009; Hall et al., 2012). Season has also been shown to influence some phenotypic traits affecting marketability of baby-leaf lettuce, such as leaf color and flavor (Bunning et al., 2010; Marin et al., 2015). Interactions between cultivar performance, production season and trial location underscore the importance of evaluating cultivars at multiple sites within a region and over multiple seasons before selecting cultivars for that region. Fluctuation in cultivar performance across years, seasons, and planting dates suggests that growers should plant a diverse array of crops for baby-leaf salad to protect from crop loss and to achieve overall yield stability. This strategy lends itself well to baby-leaf salad production as consumers accept a diversity of cultivars in baby-leaf salad mix from harvest to harvest as well as from season to season (Glaser et al., 2001; Hardesty, 2010). Given the variability of performance observed within cultivars in this study, application of

Table 3. Marketable weight $\left(\mathrm{t} \cdot \mathrm{ha}^{-1}\right)$ for nine leafy green crop cultivars grown as baby-leaf salad in two staggered plantings at Cloud Mountain Farm Center (CMFC) and Washington State University Northwestern Washington Research and Extension Center (NWREC) in Spring 2013 and 2014 , and Fall 2012 and 2013.

\begin{tabular}{|c|c|c|c|c|c|c|c|c|c|c|c|}
\hline \multirow[b]{3}{*}{ Planting } & \multicolumn{6}{|c|}{ Spring } & \multicolumn{5}{|c|}{ Fall } \\
\hline & \multicolumn{3}{|c|}{ CMFC } & \multicolumn{3}{|c|}{ NWREC } & \multicolumn{3}{|c|}{ CMFC } & \multicolumn{2}{|c|}{ NWREC } \\
\hline & $1^{\mathrm{x}}$ & $2^{\mathrm{x}}$ & $\mathrm{C}^{\mathrm{w}} 2$ & $1^{\mathrm{x}}$ & $2^{\mathrm{x}}$ & $\overline{\mathrm{C}}$ & $1^{\mathrm{x}}$ & $2^{x}$ & $\frac{2013^{y}}{C}$ & $\frac{2012^{y}}{C 2}$ & $\frac{2013^{y}}{C}$ \\
\hline Yukina Savoy & $0 \mathrm{e}^{\mathrm{v}}$ & $11.73 \mathrm{cde}$ & $5.47 \mathrm{~b}$ & $5.97 \mathrm{ab}$ & $7.57 \mathrm{bc}$ & 2.23 & $9.15 \mathrm{a}$ & $10.08 \mathrm{a}$ & $12.45 \mathrm{~b}$ & $4.85 \mathrm{ab}$ & $8.81 \mathrm{~b}$ \\
\hline Komatsuna & $4.05 \mathrm{~d}$ & $16.81 \mathrm{bc}$ & $8.36 \mathrm{a}$ & $7.69 \mathrm{~b}$ & $20.59 \mathrm{a}$ & 4.83 & $6.72 \mathrm{ab}$ & $5.11 \mathrm{~d}$ & $15.48 \mathrm{a}$ & $7.61 \mathrm{a}$ & $11.11 \mathrm{a}$ \\
\hline Joi Choi & $4.52 \mathrm{~d}$ & $24.29 \mathrm{ab}$ & $10.44 \mathrm{a}$ & $1.31 \mathrm{c}$ & $14.60 \mathrm{a}$ & 6.32 & $6.37 \mathrm{ab}$ & $7.29 \mathrm{bc}$ & $15.53 \mathrm{a}$ & $8.00 \mathrm{a}$ & $21.40 \mathrm{a}$ \\
\hline Bull's Blood & $14.83 \mathrm{bc}$ & $12.81 \mathrm{~cd}$ & $3.85 \mathrm{c}$ & $10.43 \mathrm{ab}$ & $4.49 \mathrm{c}$ & 3.55 & $4.64 \mathrm{bc}$ & $5.37 \mathrm{~cd}$ & $4.19 \mathrm{c}$ & $4.25 \mathrm{ab}$ & $2.40 \mathrm{c}$ \\
\hline Arugula Adagio & $0 \mathrm{e}$ & $6.35 \mathrm{de}$ & $4.44 \mathrm{bc}$ & $8.19 \mathrm{ab}$ & $8.01 \mathrm{ab}$ & 4.05 & - $^{t}$ & - & - & - & - \\
\hline Winter Red & $8.72 \mathrm{~cd}$ & $17.45 b c$ & $5.39 \mathrm{~b}$ & $6.25 \mathrm{bc}$ & $17.05 \mathrm{a}$ & 7.40 & - & - & - & - & - \\
\hline El Real & $21.08 \mathrm{ab}$ & $12.85 \mathrm{~cd}$ & $3.89 \mathrm{c}$ & - & $4.79 \mathrm{c}$ & 3.93 & - & - & - & - & - \\
\hline$P$ value & 0.0001 & 0.0001 & 0.0001 & 0.01 & 0.002 & 0.08 & 0.049 & 0.008 & 0.0001 & 0.08 & 0.0001 \\
\hline
\end{tabular}

${ }^{2}$ Raw data failed to satisfy the assumptions of normality for analysis of variance (ANOVA). The square root transformation of data was determined to be the best transformation meeting analysis assumptions (Kirk 1982), therefore, the log of these data were analyzed.

${ }^{y}$ Raw data failed to satisfy the assumptions of normality for ANOVA. Log transformation of data was determined to be the best transformation meeting analysis assumptions (Kirk 1982), therefore, the log of these data were analyzed.

${ }^{\mathrm{x}}$ No transformation satisfied the assumptions of normality for ANOVA; therefore data were nonparametrically transformed using PROC RANK (SAS version 9.3 for Windows; SAS Institute, Cary, NC).

wPlanting dates combined because of lack of statistically significant interaction between planting date and cultivar.

'Means separations determined using Fisher's least significant difference test.

"Crop failure.

'Crop not planted. 
Table 4. Days to harvest (DTH) for nine leafy green crop cultivars grown as baby-leaf salad in two staggered plantings at Cloud Mountain Farm Center (CMFC) and Washington State University Northwestern Washington Research and Extension Center (NWREC) in Spring 2013 and 2014 , and Fall 2012 and 2013.

\begin{tabular}{|c|c|c|c|c|c|c|c|c|c|c|c|c|}
\hline \multirow[b]{3}{*}{ Planting } & \multicolumn{6}{|c|}{ Spring } & \multicolumn{6}{|c|}{ Fall } \\
\hline & \multicolumn{4}{|c|}{ CMFC } & \multicolumn{2}{|c|}{ NWREC } & \multicolumn{3}{|c|}{ CMFC } & \multicolumn{3}{|c|}{ NWREC } \\
\hline & $1^{z}$ & $2^{z}$ & $1^{z}$ & $2^{z}$ & $\frac{2013^{\mathrm{z}}}{\mathrm{C}^{\mathrm{y}}}$ & $\frac{2014^{z}}{C}$ & $\frac{2012^{z}}{\mathrm{C}}$ & $1^{z}$ & $2^{z}$ & $1^{z}$ & $2^{z}$ & $\frac{2013^{\mathrm{z}}}{\mathrm{C}}$ \\
\hline Yukina Savoy & $36 c^{x}$ & $31 \mathrm{a}$ & $41 \mathrm{~b}$ & $33 \mathrm{a}$ & $41 \mathrm{~cd}$ & $38 \mathrm{ab}$ & $49 \mathrm{~b}$ & $40 \mathrm{~b}$ & $60 \mathrm{~b}$ & $36 \mathrm{~cd}$ & $86 \mathrm{c}$ & $64 \mathrm{e}$ \\
\hline Komatsuna & $30 \mathrm{a}$ & $31 \mathrm{a}$ & $37 \mathrm{a}$ & $33 \mathrm{a}$ & $34 \mathrm{ab}$ & $36 \mathrm{a}$ & $35 \mathrm{a}$ & $30 \mathrm{a}$ & $39 \mathrm{a}$ & $28 \mathrm{ab}$ & $23 \mathrm{a}$ & $37 \mathrm{ab}$ \\
\hline Joi Choi & $30 \mathrm{a}$ & $31 \mathrm{a}$ & $37 \mathrm{a}$ & $33 \mathrm{a}$ & $33 \mathrm{a}$ & $37 \mathrm{a}$ & $35 \mathrm{a}$ & $30 \mathrm{a}$ & $39 \mathrm{a}$ & $28 \mathrm{ab}$ & $36 \mathrm{~b}$ & $63 \mathrm{e}$ \\
\hline Arugula Adagio & $36 \mathrm{c}$ & $31 \mathrm{a}$ & $43 \mathrm{~b}$ & $33 \mathrm{a}$ & $37 a b c$ & $39 \mathrm{~b}$ & $-^{v}$ & - & - & - & - & - \\
\hline Winter Red & $34 \mathrm{~b}$ & $31 \mathrm{a}$ & $37 \mathrm{a}$ & $33 \mathrm{a}$ & $38 \mathrm{bcd}$ & $37 \mathrm{a}$ & - & - & - & - & - & - \\
\hline El Real & $36 \mathrm{c}$ & $31 \mathrm{a}$ & $43 \mathrm{~b}$ & $33 \mathrm{a}$ & - & $39 \mathrm{~b}$ & - & - & - & - & - & - \\
\hline$P$ value & 0.0001 & 0.0001 & 0.0001 & 0.0001 & 0.0001 & 0.04 & 0.0001 & 0.0001 & 0.0001 & 0.005 & 0.0001 & 0.0001 \\
\hline
\end{tabular}

${ }^{\mathrm{z}}$ No transformation satisfied the assumptions of normality for analysis of variance; therefore data were nonparametrically transformed using PROC RANK (SAS version 9.3 for Windows; SAS Institute, Cary, NC).

${ }^{y}$ Planting dates combined because of lack of statistically significant interaction between planting date and cultivar.

${ }^{\mathrm{x}}$ Means separations determined using Fisher's least significant difference test.

${ }^{\mathrm{w}}$ Crop failure.

${ }^{\mathrm{v}}$ Crop not planted.

microclimate control technologies such as low and high tunnels to control root and shoot zone temperature will likely provide growers with greater control of baby-leaf crop performance than will cultivar selection (Rader and Karlsson, 2006).

The fluctuation in cultivar performance observed in this study may be due to the methods whereby salad crop cultivars for baby-leaf salad production have been developed. Many salad crop cultivars grown for baby leaf mix, including those evaluated in this study, were initially developed for harvest as mature leaves (Kuepper et al., 2002; Ryder, 2002). While development of cultivars specifically for baby-leaf salad production is becoming increasingly common, currently a limited number of traits are assessed during the breeding process, including attractive leaf shape and color at the seedling stage and postharvest shelf life (Hayes et al., 2014; Martinez-Sanchez et al., 2012). It would likely be possible to address unpredictable cultivar performance at the baby leaf growth stage by evaluating and selecting for cultivar yield stability at the optimal leaf size for baby leaf $(\approx 10 \mathrm{~cm})$.

Though cultivar performance was variable in this study, an overall comparison of cultivar performance across season, location, year, and planting date reveals that pak choi cv. Joi Choi had a high marketable weight, a relatively quick time to harvest, and high weed competitiveness. Mustard 'Komatsuna' also had one of the highest marketable weights, as well as the lowest DTH and highest weed competitiveness. Beet 'Bull's Blood' performed poorly in this study, with consistently low weight, a relatively long DTH, as well as poor weed competitiveness. Lettuce 'Brown Goldring' is a romaine type commonly grown for baby-leaf salad production, but it had the longest DTH overall, which is not desirable for baby-leaf production. Yet lettuce is one of the most desirable crops for salad mix and year-round availability of baby-leaf lettuce is demanded by United States retailers and consumers (Glaser et al., 2001), therefore, there is a need to identify cultivars that are well suited to extended season production.

In the spring growing season, cultivars had higher marketable weight and shorter DTH than in the fall season. These results are similar to those of other studies that have observed seasonal differences in yield in baby-leaf arugula and lettuce crops (Fallovo et al., 2009; Hall et al., 2012). Weed biomass in this study was also greater in the spring than in the fall. These differences were likely attributable to the increasing temperature and daylength in the spring, which increased

Table 5. Weed fresh biomass (t.ha $\left.{ }^{-1}\right)$ for nine leafy green crop cultivars grown as baby-leaf salad in two staggered plantings at Cloud Mountain Farm Center (CMFC) and Washington State University Northwestern Washington Research and Extension Center (NWREC) in Spring 2013 and 2014 , and Fall 2013.

\begin{tabular}{|c|c|c|c|c|c|c|c|c|c|}
\hline \multirow[b]{3}{*}{ Planting $^{\mathrm{w}}$} & \multicolumn{5}{|c|}{ Spring } & \multicolumn{4}{|c|}{ Fall } \\
\hline & \multicolumn{3}{|c|}{ CMFC } & \multicolumn{2}{|c|}{ NWREC } & \multicolumn{2}{|c|}{$\frac{C M F C}{2013^{x}}$} & \multicolumn{2}{|c|}{ NWREC } \\
\hline & $1^{\mathrm{w}}$ & $2^{\mathrm{w}}$ & $\mathrm{C}^{\mathrm{v}}$ & $\begin{array}{c}2013^{y} \\
C\end{array}$ & $\frac{2014^{y}}{C}$ & $1^{\mathrm{w}}$ & $2^{\mathrm{w}}$ & $\frac{2012^{y}}{C}$ & $\frac{2013^{y}}{C}$ \\
\hline Yukina Savoy & $1.00 \mathrm{ab}^{\mathrm{u}}$ & $1.09 \mathrm{~cd}$ & $0.79 \mathrm{bc}$ & $0.92 \mathrm{bc}$ & 0.49 & $0.17 \mathrm{~b}$ & $0.44 \mathrm{a}$ & $1.07 \mathrm{a}$ & $0 \mathrm{~b}$ \\
\hline Komatsuna & $0.15 \mathrm{c}$ & $0.31 \mathrm{de}$ & $0.27 \mathrm{~d}$ & $0.49 \mathrm{~cd}$ & 0.31 & $0.03 \mathrm{c}$ & $0.01 \mathrm{~b}$ & $0 \mathrm{c}$ & $0.04 \mathrm{~b}$ \\
\hline Joi Choi & $0.19 \mathrm{c}$ & $1.59 \mathrm{c}$ & $0.41 \mathrm{~cd}$ & $0.16 \mathrm{~d}$ & 0.29 & $0.04 \mathrm{c}$ & $0.03 \mathrm{~b}$ & $0.03 \mathrm{c}$ & $0.05 \mathrm{~b}$ \\
\hline Bull's Blood & $1.25 \mathrm{a}$ & $5.95 \mathrm{ab}$ & $1.35 \mathrm{a}$ & $8.04 \mathrm{a}$ & 1.40 & $1.53 \mathrm{a}$ &..$^{t}$ & $0.15 \mathrm{ab}$ & $1.23 \mathrm{a}$ \\
\hline Arugula Adagio & $0.39 \mathrm{bc}$ & $2.20 \mathrm{bc}$ & $0.80 \mathrm{~b}$ & $1.24 \mathrm{bcd}$ & 0.99 & $-\mathrm{s}$ & - & - & - \\
\hline Winter Red & $0.65 \mathrm{abc}$ & $1.24 \mathrm{c}$ & $0.39 \mathrm{~d}$ & $2.36 \mathrm{bcd}$ & 0.28 & - & - & - & - \\
\hline E1 Real & $0.17 \mathrm{c}$ & $0.16 \mathrm{e}$ & $0.21 \mathrm{~d}$ & - & 1.57 & - & - & - & - \\
\hline$P$ value & 0.002 & 0.0001 & 0.0001 & 0.002 & 0.47 & 0.0001 & 0.0006 & 0.007 & 0.0494 \\
\hline
\end{tabular}

${ }^{\mathrm{z}}$ Raw data failed to satisfy the assumptions of normality for analysis of variance (ANOVA). The square root transformation of data was determined to be the best transformation meeting analysis assumptions, therefore, the square root of these data were analyzed.

${ }^{y}$ Raw data failed to satisfy the assumptions of normality for ANOVA. Log transformation of data was determined to be the best transformation meeting analysis assumptions (Kirk 1982), therefore, the log of these data were analyzed.

${ }^{x}$ No weed biomass data were collected at CMFC in Fall 2012.

"No transformation satisfied the assumptions of normality for ANOVA; therefore data were nonparametrically transformed using PROC RANK (SAS version 9.3 for Windows; SAS Institute, Cary, NC).

vPlanting dates combined because of lack of statistically significant interaction between planting date and cultivar.

"Means separations determined using Fisher's least significant difference test.

${ }^{\mathrm{t}}$ Crop failure.

${ }^{\mathrm{s}} \mathrm{Crop}$ not planted. 
growth rate in both crops and weeds. The contrasting trend toward lower temperature and shorter daylength in the fall season contributed to slower growth rate, particularly as the crop neared harvest, leading to longer DTH. These results indicate that weed management strategies and good soil preparation methods to optimize rapid crop stand establishment are more important in spring than in fall for baby-leaf salad crop production, while season extension techniques (rowcover and low and high tunnels) are more important for fall than for spring production. Further, the average yield for baby-leaf salad mix in this study as compared with the Salinas Valley, CA (20.8 tha ${ }^{-1}$; Monterey County Crop Report, 2013 ) was $66 \%$ in the spring and $44 \%$ in the fall, suggesting that more work is needed to determine optimum production techniques for northwest Washington.

\section{Literature Cited}

Borrelli, K., R.T. Koenig, B.M. Jaeckel, and C.A. Miles. 2013. Yield of leafy greens in high tunnel winter production in the northwest United States. HortScience 48:183-188.

Bumgarner, N.R., M.A. Bennett, P.P. Ling, R.W. Mullen, and M.D. Kleinhenz. 2011. Canopy cover and root-zone heating effects on fall- and spring-grown leaf lettuce yield in Ohio. HortTechnology 21:737-744.

Bunning, M.L., P.A. Kendall, M.B. Stone, F.H. Stonaker, and C. Stushnoff. 2010. Effects of seasonal variation on sensory properties and total phenolic content of 5 lettuce cultivars. J. Food Sci. 75(3):S156-S161.

City of Salinas Office of Economic Development. 2013. Agriculture and Agribusiness. 19 July 2014. <http://www.businessinsalinas.com/KeyIndustries/Agriculture-Agribusiness.aspx/>.

Clarkson, G.J., E.E. O’Byrne, S.D. Rothwell, and G. Taylor. 2003. Identifying traits to improve postharvest processability in baby leaf salad. Postharvest Biol. Technol. 30(3):287-298.

Cook, R. 2008. Trends in the Marketing of Fresh Produce and Fresh-Cut Products. Univ. Cal. Davis. 15 July 2013. <http://ucanr.edu/datastoreFiles/ 234-2435.pdfs

Coolong, T., D.M. Law, J.C. Snyder, B. Rowell, and M.A. Williams. 2013. Organic leafy greens variety trials in Kentucky: Identifying superior varieties for small-scale organic farmers. HortTechnology 23:241-246.

Dalla Costa, L., N. Tomasi, S. Gottardi, F. Iacuzzo, G. Cortella, L. Manzocco, R. Pinton, T. Mimmo, and S. Cesco. 2011. The effect of growth medium temperature on corn salad [Valerianella locusta (L.) Laterr] baby leaf yield and quality. HortScience 46:1619-1625.

Egea-Gilabert, C., D. Niñirola, E. Conesa, M.E. Candela, and J.A. Fernández. 2013. Agronomical use as baby leaf salad of Silene vulgaris based on morphological, biochemical and molecular traits. Sci. Hort. 152:35-43.

Fallovo, C., Y. Rouphael, M. Cardarelli, E. Rea, A. Battistelli, and G. Colla. 2009. Yield and quality of leafy lettuce in response to nutrient solution composition and growing season. J. Food Agr. Environ. 7(2):456-462.

Farnham, M.W. and J.T. Garrett. 1996. Importance of collard and kale genotype for winter production in southeastern United States. HortScience 31:1210-1214.

Freitas, K.K.C., F.B. Neto, L.C. Grangeiro, J.S.S Lima, and K.H.S. Moura. 2009. Agronomic performance of rocket under different spacing and planting times. Revista Ciência Agronômica. 40(3):449-454.

Glaser, L.K., G.D. Thompson, and C.R. Handy. 2001. Recent changes in marketing and trade practices in the U.S. lettuce and fresh-cut vegetable industries. Econ. Res. Rpt. 767. U.S. Dept. Agr., Washington, DC.

Hall, M.K.D., J.J. Jobling, and G.S. Rogers. 2012. Factors affecting growth of perennial wall rocket and annual garden rocket. J. Veg. Sci. $18: 393-411$.

Hardesty, S. 2010. Spring mix case studies in the Sacramento area: Comparing the structure, size and performance of local and mainstream food supply chains. Econ. Res. Rpt. 99. U.S. Dept. Agr., Washington, DC.

Hardesty, S. and P. Leff. 2009. Determining marketing costs and returns in alternative marketing channels. Renew. Agr. Food Syst. 25:24-34.

Hayes, R.J., M.A. Trent, B. Mou, I. Simko, S.J. Gebben, and C.T. Bull. 2014. Baby leaf lettuce germplasm enhancement: Developing diverse populations with resistance to bacterial leaf spot caused by Xanthomonas campestris pv. vitians. HortScience 49:18-24.

Hoque, M.M., H. Ajwa, M. Othman, R. Smith, and M. Cahn. 2010. Yield and postharvest quality of lettuce in response to nitrogen, phosphorus, and potassium fertilizers. HortScience 45:1539-1544.

Kirk, R.E. 1982. Experimental design: Procedures for the behavioral sciences. 2nd ed. Brooks Cole Publishing Company, Belmont, CA.

Koike, S., M. Cahn, M. Cantwell, S. Fennimore, M. LeStrange, E. Natwick, and E. Takele. 2011. Spinach production in California. Univ. Calif. Div. Agr. Nat. Resources Publ., 7212.

Kuepper, G., J. Bachmann, and R. Thomas. 2002. Specialty Lettuce and Greens: Organic Production. Appropriate Technology Transfer for Rural Areas, Fayetteville, AR. 15 Apr. 2015.
$<$ https://attra.ncat.org/attra-pub/viewhtml.php? id $=375>$.

Marin, A., F. Ferreres, G.G. Barbera, and M.I. Gil. 2015. Weather variability influences color and phenolic content of pigmented baby leaf lettuces throughout the season. J. Agr. Food Chem. 63(6):1673-1681.

Martinez-Sanchez, A., M.C. Luna, M.V. Selma, J.A. Tudela, J. Abad, and M.I. Gil. 2012. Babyleaf and multi-leaf of green and red lettuces are suitable raw materials for the fresh-cut industry. Postharvest Biol. Tec. 63:1-10.

Monterey County Agricultural Commission. 2012. 2012 Monterey County crop report. Mont. County Ag. Comm., Salinas, CA.

Rader, H.B. and M.G. Karlsson. 2006. Northern field production of leaf and romaine lettuce using a high tunnel. HortTechnology 16:649654.

Reader, L. 2003. Lettuce for the cool season. Univ. Ariz. Coop. Ext. Maricopa County Hort. News and Res. J. 18 Mar. 2010. <http://ag.arizona.edu/ maricopa/garden/html/pubs/1203/landscaping. html>.

Ryder, E.J. 2002. The new salad crop revolution, p. 408-412. In: J. Janick and A. Whipkey (eds.). Trends in new crops and new uses. ASHS Press, Alexandria, VA.

Sanchez, C.A. and N.M. El-Hout. 1995. Response of diverse lettuce types to fertilizer phosphorus. HortScience 30:528-531.

Smith, R., S. Cahn, O. Daugovish, S. Koike, E. Natwick, H. Smith, K. Subbarao, E. Takele, and T. Turine. 2011. Leaf lettuce production in California. Univ. Cal. Ag. Nat. Resources Publ. 7216.

Thompson, G.D. and P.N. Wilson. 1999. Market demands for bagged, refrigerated salads. J. Agr. Resource Econ. 24:463-481.

United States Department of Agriculture. 2010. U.S. leaf and romaine lettuce: Supply, utilization, and price. U.S. Dept. Agr., Washington, D.C.

United States Department of Agriculture. 2012a. Web Soil Survey. U.S. Dept. Agr., Washington, DC.

United States Department of Agriculture. 2012b. Vegetable consumption per capita. U.S. Dept. Agr., Washington, DC.

United States Department of Agriculture. 2014. 2013 Vegetables summary. U.S. Dept. Agr., Washington, DC.

Wallace, R.W., A.L. Wszelaki, C.A. Miles, J.S. Cowan, J. Martin, J. Roozen, and D.A. Inglis. 2012. Lettuce yield and quality when grown in high tunnel and open-field production systems under three diverse climates. HortTechnology 22:659-668.

Zhao, X. and E.E. Carey. 2009. Summer production of lettuce, and microclimate in high tunnel and open field plots in Kansas. HortTechnology 19:113-119. 